\title{
Decubitus Ulcer in a Patient with Non-Hodgkin Linfoma Treated with Topic Collagenase with Hyaluronic Acid and PRP: Case Report and Literature Review
}

\author{
Onesti $\mathbf{M G}^{1}$, Fino $\mathbf{P}^{1^{\star}}$, Ferrazza $\mathbf{G}^{2}$, Kaciulyte $\mathbf{J}^{1}$ and Scuderi $\mathbf{N}^{1}$
}

${ }^{1}$ Department of Plastic, Reconstructive and Aesthetic Surgery, University of Rome "Sapienza", Policlinico Umberto I, Viale del Policlinico, 155, 00161, Rome, Italy

${ }^{2}$ Department of Cellular Biotechnologies and Hematology, University of Rome "Sapienza”, Policlinico Umberto I, Viale del Policlinico, 155, 00161, Rome, Italy

"Corresponding author: Pasquale Fino, Department of Plastic, Reconstructive and Aesthetic Surgery, University of Rome " La Sapienza”, Policlinico Umberto I, Viale Pantelleria, 35, Scala B, Interno 1/A, 00141, Rome, Italy, Tel: 39 3334571756; Fax: +39 06/491525/+39 06 64491523; E-mail: pasquale.fino@gmail.com, pasquale.fino@uniroma1.it

Received date: Aug 21 2014, Accepted date: Aug 18, 2015, Publication date: Aug 21, 2015

Copyright: (c) 2015 Onesti MG, et al. This is an open-access article distributed under the terms of the Creative Commons Attribution License, which permits unrestricted use, distribution, and reproduction in any medium, provided the original author and source are credited.

\begin{abstract}
Introduction: Gradual increase in the elderly population in recent years is posing great health challenges and ulcers are one of the major challenges for the patients that are bedridde due to hematologic issues. They are commonly affected by ulcers. Beyond standard treatments, new approach to treat skin ulcers has become the application of topical growth preparations as PRP.

Case Report: We are reporting a case of a 62-year-old male patient affected by non-Hodgkin Linfoma with paraparesis due to a compression over the bone marrow caused due to Linfoma. The prolonged bedridden condition had led to a voluminous class III-IV decubitus ulcer in the sacral region of $20 \times 15 \mathrm{~cm}$. We performed a standard medication for the injury for 5 weeks, which consisted in traditional disinfection, cleansing with physiological solution and application of topic collagenase. There was improvement and the wound started healing gradually, when treatmented with 8 cycles of piastrinic gel therapy. After six weeks of PRP treatment, the patient exhibited tremendous improvement.
\end{abstract}

Production of hemocomponent: The platelet gel was obtained by autologous automatic procedure with multicomponent collection. The platelet count was significantly high and the WBC count was 10 times higher than baseline values of peripheral blood. Cryoprecipitate was obtained and mixed with leucoplatelet concentrate for enrichment and then splitted into 8 small bags. We succeed to reach a high cellular concentration without G-CSF patient stimulation and the procedure was well tolerated by the patient.

Discussion: PRP method consists of collection and concentration of platelets that can release powerful growthfactors and there by cure the wound. Its positive effect is due to released lipoxins, antimicrobial effects, recruitment of undifferentiated cells and promotion of type I collagen formation and MMPs gene expression. It is a cheap and minimally invasive method. A quick review of literature and medical cases reveled the proofs for skin ulcers treated with PRP. This is helpful in treating the present case affected with skin ulcersand the study discusses how this can be managed through PRP application.Conclusion: The study concludes that it is possible to reduce the diameter of the soer and clear the bottom by applying PRP for a patient suffering from non-Hodgkin Linfoma. The study couold prove this treatment as safe with no risk of infection and it improves the quality of life of the patient. This study could establish that PRP application ensures faster healing with minimal or no hospitalization and very low medication.

Keywords: Decubitus ulcer; Autologous PRP treatment; Hematologic patients

\section{Introduction}

NPUAP defines the Pressure ulcers as: "localized injury to the skin and/or underlying tissue usually over a bony prominence as a result of pressure, or pressure in combination with shear and/or friction" [1]. 2.5 million pressure sore cases are treated in the United States alone annually [2].

Leg ulcerations are really common in hemolytic anemias, like sickle cell disease. They have a multifactorial etiology, with compromised blood supply as the main factor [3]. Another group of hematologic patients are the one that are affected by the $\beta$-thalassemia intermedia, with a prevalence of $8 \%$ with leg ulcers [4].
Pressure over prominent bones leading to cuts, skin destruction, and the bleeding are the major symptoms noticed in the physiology path of the pressure ulcers.

Pressure over bony prominence, with a cut, skin destruction and compromised blood flow are the main points in the path physiology of pressure ulcers. New researches brought the evidence that ischemia, more than the pressure, is the main agent that causes pressure ulcers [5].

Gradual rise in the elderly population in recent years has made the skin ulcers a very important problem [6]. Pain management is difficult and the treatment is very expensive [7]. Almost \$ 5 billion are spent each year in the US alone to treat these pressure ulcers [8], while the treatment cost for a single wound is $\$ 70,000$ [9]. 
Citation: Onesti MG, Fino P, Ferrazza G, Kaciulyte J, Scuderi N (2015) Decubitus Ulcer in a Patient with Non-Hodgkin Linfoma Treated with Topic Collagenase with Hyaluronic Acid and PRP: Case Report and Literature Review. J Blood Disord Transfus 6: 298. doi: $10.4172 / 2155-9864.1000298$

Page 2 of 5

Debridement, minimization of weight bearing, application of dermal substitutes and VAC therapy are the standard treatments applied to cure o these type of wounds [10-12]. Application of topical growth preparations as an adjuvant treatment is a new approach to treat the skin ulcers $[13,14]$. This faster way treating the skin ulcers improves the quality of life of the people affected with skin ulcers with reduced cost.

\section{Case Report}

62-year-old male patient affected by non-Hodgkin Linfoma appraoched us with the ambulatory of ulcers and severe wounds on March 2011. The patient presented a voluminous class III-IV decubitus ulcer in the sacral region of $20 \times 15 \mathrm{~cm}$. The wound was particularly fibrinous with abundant necrotic tissue formation on the surface (Figure 1). CHOP chemotherapy (Cilofosfamide, Doxorubicina, Vincristina, Prednisone) had lead the patient to an advanced stadium of his pathology. The non-Hodgkin Linfoma created a compression over the bone marrow, causing paraparesis which lead to a prolonged bedridden that caused the pressure sore.

Considering the highly precarious condition of the patient, associated with particularly advanced lesion, we have decided to adopt the conservative approach initially. It was based on traditional disinfection with sodium hypochlorite solution of $0,05 \%$ (Amukine Med $^{\oplus}$ 0,05\%, Amuchina SpA, Genova, Italia) and povidone iodine of $10 \%$ (Betadine $10 \%$, Meda Pharma SpA, Milano, Italia), cleansing with physiological solution and application of topic collagenase (Bionect Start ${ }^{\circ}$ ) with purpose view to reduce the necrotic layer and the superficial fibrosis (Figure 2). This medication was applyed for 5 weeks, 3 times per week at our ambulatory and daily at home.

There was considerable improvement as the wound reduced in size with sores getting dry with 8 layers of PRP application for a period of one week. The patient could not continue this treatment after six weeks as his condition got worsened and was admitted in a hospital, where he died after few weeks (Figure 3).

Anyhow, after 6 weeks of applications of piastrinic gel, a strong melioration of the pressure sore was observed: the diameter of the lesion reduced and the ulcer's bottom clearly improved (Figure 4).

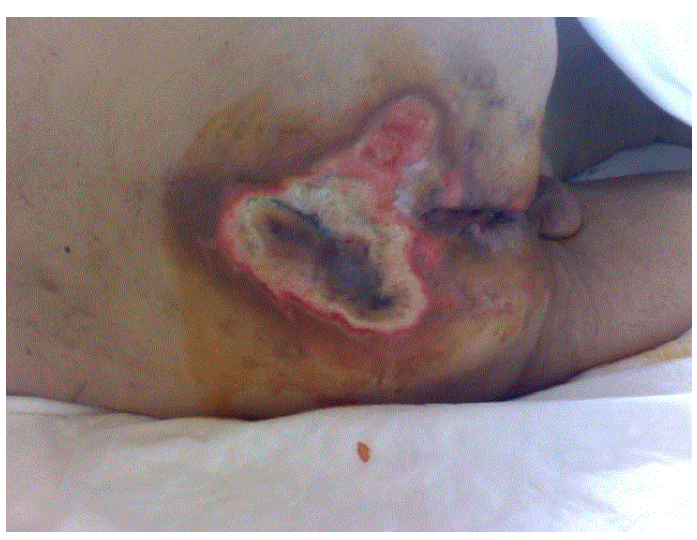

Figure 1: Decubitus ulcer at our first observation.

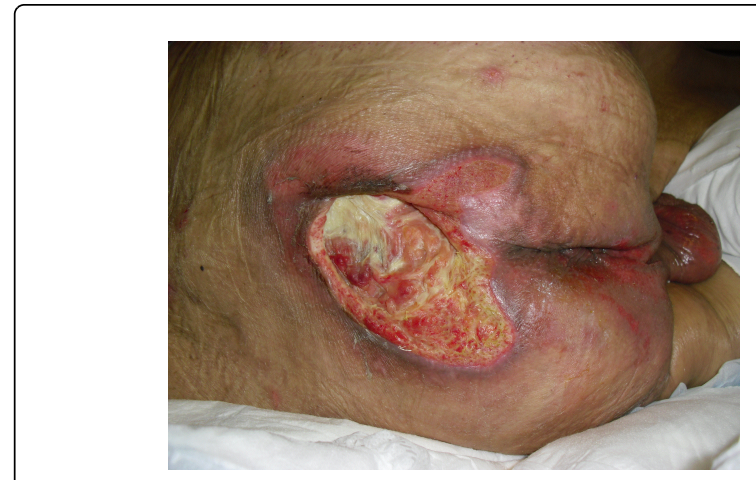

Figure 2: The ulcer after 5 weeks of treatment with collagenase with hyaluronic acid.

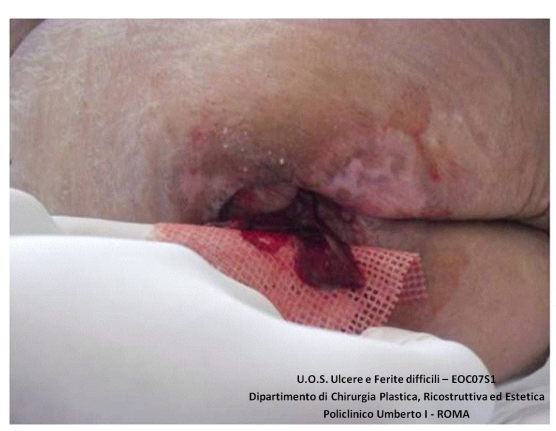

Figure 3: The ulcer with PRP application.

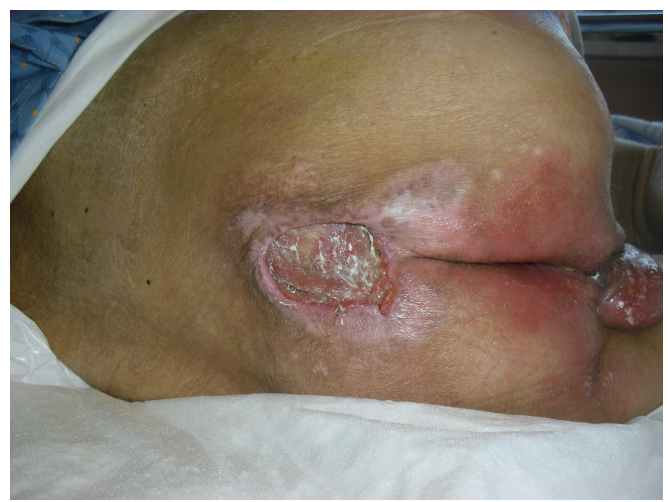

Figure 4: The ulcer after 6 weeks of treatment with PRP.

\section{Production of Hemocomponent}

Platelet gel is obtained by autologous automatic procedure with multi-component collection using Haemonetics MCS $+^{\oplus}$ (Haemonetics Corp., Braintree, MA, USA) cell separator and a disposable (code 971E) for peripheral blood stem cell collection using a modified protocol. $60 \mathrm{ml}$ of leucoplatelet concentrate and almost $200 \mathrm{ml}$ of plasma were produced in a span of one hour. The platelet count was significantly high with more than $4,800 \times 10^{3} / \mu \mathrm{l}$, the WBC count was 10 times higher than baseline values of peripheral blood. 
Citation: Onesti MG, Fino P, Ferrazza G, Kaciulyte J, Scuderi N (2015) Decubitus Ulcer in a Patient with Non-Hodgkin Linfoma Treated with Topic Collagenase with Hyaluronic Acid and PRP: Case Report and Literature Review. J Blood Disord Transfus 6: 298. doi: $10.4172 / 2155-9864.1000298$

Page 3 of 5

Cryoprecipitate was obtained from plasma thawed overnight to $4^{\circ} \mathrm{C}$ This fraction was mixed with leucoplatelet concentrate for enrichment with fibrinogen and other extracellular matrix proteins (fibronectine) and splitted into 8 small bags. In this way, it is possible to get topical hemocomponent that can be used for several applications with one autologous procedure. The leucoplatelet gel was made of autologous thrombin, cryoprecipitate-enriched platelet concentrate and gluconate of calcium. With this very cheap autologous procedure we succeed to reach a high cellular concentration without G-CSF patient stimulation, even if patient haematocrit was no more than $30 \%$. The autologous procedure was well tolerated by patient and no side effects were observed.

\section{Discussion}

Platelet-rich plasma (PRP) method consists of collection and concentration of platelets (autologous or heterologous) that can release powerful growth-factors from their alpha and dense granules: PDGF, VEGF, TGF $\beta$, FGF, EGF. All of them have the power to help tissue regeneration and cellular recruitment in the treated lesion. There are also the lipoxins, which are anti-inflammatory mediators [15-21]. This jel is an, antimicrobial, which can be used to fight against E coli, Candida albicans, MRSA and Cryptococcus neoformans [22]. PRP application can attract even the undifferentiated cells to the injury and promote angiogenesis and re-epithelialization [23]. PRP is $t$ a potential remodel to fight the aged skin by using its ability to promote type I collagen formation and MMPs gene expression [24].

PRP method is also less expensive than single amount of isolated human factors. It is also minimally invasive, as it requires only small blood samples for each time [25]. Another advantage of using PRP instead of single amounts of human isolated growth factors is that PRP contains naturally balanced quantities of the growth factors, therefore it acts more likely to a physiological healing process [26-28].There are several systems to deliver PRP to the wound. Thrombin, $\mathrm{CaCl}_{2}$, alginate beds, can be used for this purpose [29].

Our case report carries out the evidence that PRP therapy can improve the healing of pressure wounds even among debilitated patients as hematologic ones. By fastening the ulcers' healing process, this medication is improving the patients' conditions and their life quality.

Relavent review of literature and medical cases of skin ulcers treated with PRP are give in the Table 1. According to it, Scott et al. have showed in their case report [29] on how the right trochanter ulcer in a spinal cord injured patient that responded well to the PRP therapy with the development of tissue granulation, vascularization and epithelialization.

PRP can also successfully treat other kinds of ulcers, such as diabetic ones. This was demonstrated by Masoud Mehrannia et al. in the case of a diabetic patient with leg injuries [30]. Using PRP method, they managed to treat the wounds that were non responsive to traditional treatments. Dai Hyun Kim et al. [31] have achieved similar results by using PRP treatment on an old woman (94 year) who had a severe leg ulcer in a situation of various comorbidities. The lesion was not improving with daily simple dressings and periodic debridement. However, PRP could fill the granulation tissue and cure the wound in a span of two months.

\begin{tabular}{|c|c|c|c|c|}
\hline Article and Authors & $\begin{array}{l}\text { Number of } \\
\text { Patients }\end{array}$ & Skin Wounds & PRP Treatment & Time of Treatment \\
\hline $\begin{array}{l}\text { Sell et al. A case report on the use of sustained } \\
\text { release platelet-rich plasma for the treatment of } \\
\text { chronic pressure ulcers [29]. }\end{array}$ & 3 & 3 pressure ulcers & autologous & $\begin{array}{l}\text { Patient 1:8 weeks } \\
\text { Patient 2:10 prp applications } \\
\text { Patient 3:5 prp applications }\end{array}$ \\
\hline $\begin{array}{l}\text { Yuan et al. The preliminary application of autologous } \\
\text { platelet-rich gel used to treat refractory diabetic } \\
\text { dermal ulcer. }\end{array}$ & 13 & 13 diabetic ulcers & autologous & $69.2 \%$ cured in 3 weeks \\
\hline $\begin{array}{l}\text { Driver et al. A prospective, randomized, controlled } \\
\text { trial of autologous platelet-rich plasma gel for the } \\
\text { treatment of diabetic foot ulcers. }\end{array}$ & $\begin{array}{l}72 \text { divided into } \\
\text { two groups: } 40 \\
\text { for prp } \\
\text { treatment, } 32 \text { in } \\
\text { a control group }\end{array}$ & 40 diabetic ulcers & autologous & 12 weeks \\
\hline $\begin{array}{l}\text { Sakata et al. A retrospective, longitudinal study to } \\
\text { evaluate healing lower extremity wounds in patients } \\
\text { with diabetes mellitus and ischemia using standard } \\
\text { protocols of care and platelet-rich plasma gel in a } \\
\text { Japanese wound care program. }\end{array}$ & 39 & $\begin{array}{l}24 \text { ischemic diabetic, } \\
10 \quad \text { diabetic, } 5 \\
\text { ischemic, } 1 \text { pressure } \\
\text { ulcers }\end{array}$ & autologous & $83 \%$ in 145.2 days \\
\hline $\begin{array}{l}\text { Cervelli et al. Application of enhanced stromal } \\
\text { vascular fraction and fat grafting mixed with PRP in } \\
\text { post-traumatic lower extremity ulcers. }\end{array}$ & 10 & $\begin{array}{l}\text { Post traumatic low } \\
\text { extremity ulcers }\end{array}$ & Fat grafting + prp & $97.8 \%$ in 9.7 weeks \\
\hline $\begin{array}{l}\text { Cervelli et al. Application of platelet-rich plasma in } \\
\text { plastic surgery: clinical and in vitro evaluation. }\end{array}$ & 18 & $\begin{array}{l}\text { Chronic lower } \\
\text { extremity ulcers }\end{array}$ & Fat grafting + prp & $88.9 \%$ in 9.7 weeks \\
\hline $\begin{array}{l}\text { Kim et al. Application of platelet-rich plasma } \\
\text { accelerates the wound healing process in acute and } \\
\text { chronic ulcers through rapid migration and } \\
\text { upregulation of cyclin } \mathrm{A} \text { and CDK } 4 \text { in } \mathrm{HaCaT} \text { cells. }\end{array}$ & 16 & $\begin{array}{l}11 \text { chronic and } 5 \\
\text { acute ulcers }\end{array}$ & autologous & $\begin{array}{l}9 \text { of chronic ulcers healed in } 15,18 \text { days, } \\
\text { the acute ones in } 4-20 \text { days }\end{array}$ \\
\hline
\end{tabular}


Citation: Onesti MG, Fino P, Ferrazza G, Kaciulyte J, Scuderi N (2015) Decubitus Ulcer in a Patient with Non-Hodgkin Linfoma Treated with Topic Collagenase with Hyaluronic Acid and PRP: Case Report and Literature Review. J Blood Disord Transfus 6: 298. doi: $10.4172 / 2155-9864.1000298$

Page 4 of 5

\begin{tabular}{|c|c|c|c|c|}
\hline $\begin{array}{l}\text { Sarvajnamurthy et al. Autologous platelet rich plasma } \\
\text { in chronic venous ulcers: study of } 17 \text { cases. }\end{array}$ & 12 & 17 venous ulcers & autologous & 5.1 weeks \\
\hline $\begin{array}{l}\text { Martinez-Zapata et al. Autologous platelet-rich } \\
\text { plasma for treating chronic wounds. }\end{array}$ & 325 & Chronic wounds & autologous & 12 weeks ( 8 to 40 ) \\
\hline $\begin{array}{l}\text { Frykberg et al. Chronic wounds treated with a } \\
\text { physiologically relevant concentration of platelet-rich } \\
\text { plasma gel: a prospective case series. }\end{array}$ & 49 & $\begin{array}{l}\text { 65: the most common } \\
\text { were } 21 \text { pressure, } 16 \\
\text { venous and } 14 \\
\text { diabetic ulcers. }\end{array}$ & autologous & $97 \%$ improved in 2.8 weeks \\
\hline $\begin{array}{l}\text { De Angelis et al. Combined use of super-oxidised } \\
\text { solution with negative pressure for the treatment of } \\
\text { pressure ulcers: case report. }\end{array}$ & 1 & 1 pressure ulcer & $\begin{array}{l}\text { Intra- and per-lesional } \\
\text { prp injections }\end{array}$ & $\begin{array}{l}\text { Prp infections were followed by surgery, } \\
\text { after which wound reduction was } \\
\text { observed }\end{array}$ \\
\hline $\begin{array}{l}\text { Scimeca et al. Novel use of platelet-rich plasma to } \\
\text { augment curative diabetic foot surgery [13]. }\end{array}$ & 1 & Diabetic ulcer & autologous & 7 weeks \\
\hline $\begin{array}{l}\text { Masoud Mehrannia et al. Platelet Rich Plasma for } \\
\text { Treatment of Nonhealing Diabetic Foot Ulcers: A } \\
\text { Case Report [30]. }\end{array}$ & 1 & Diabetic ulcer & autologous & $\begin{array}{l}\text { Treatment of } 10 \text { days, healed in } 8 \\
\text { months }\end{array}$ \\
\hline $\begin{array}{l}\text { Knox et al. Platelet-rich plasma combined with skin } \\
\text { substitute for chronic wound healing: a case report. }\end{array}$ & 1 & Decubitus ulcer & autologous & 6 weeks \\
\hline $\begin{array}{l}\text { Saad Setta et al. Platelet-rich plasma versus platelet- } \\
\text { poor plasma in the management of chronic diabetic } \\
\text { foot ulcers: a comparative study. }\end{array}$ & 12 & Diabetic ulcers & $\begin{array}{l}\text { Prp treatment efficacy } \\
\text { was compared to } \\
\text { platelet-poor plasma } \\
\text { (ppp) control group }\end{array}$ & $? ? ?$ \\
\hline $\begin{array}{l}\text { Kim et al. Recalcitrant cutaneous ulcer of comorbid } \\
\text { patient treated with platelet rich plasma: a case } \\
\text { report. }\end{array}$ & 1 & $\begin{array}{l}\text { Traumatic cutaneous } \\
\text { ulcer }\end{array}$ & autologous & $\begin{array}{l}7 \text { applications of prp: healing in } 3 \\
\text { months }\end{array}$ \\
\hline $\begin{array}{l}\text { Nishimoto et al. Supplementation of bone marrow } \\
\text { aspirate-derived platelet-rich plasma for treating } \\
\text { radiation-induced ulcer after cardiac fluoroscopic } \\
\text { procedures: A preliminary report. }\end{array}$ & 4 & $\begin{array}{l}\text { Radiation induced } \\
\text { ulcers }\end{array}$ & $\begin{array}{l}\text { Skin flap supplemented } \\
\text { with autologous bone } \\
\text { marrow prp }\end{array}$ & $? ? ?$ \\
\hline $\begin{array}{l}\text { de Leon et al. The clinical relevance of treating } \\
\text { chronic wounds with an enhanced near-physiological } \\
\text { concentration of platelet-rich plasma gel. }\end{array}$ & 200 & 285 chronic wounds & autologous & $\begin{array}{l}96.5 \% \text { of wounds had positive results in } \\
2.2 \text { weeks }\end{array}$ \\
\hline $\begin{array}{l}\text { Dionyssiou et al. The effectiveness of intralesional } \\
\text { injection of platelet-rich plasma in accelerating the } \\
\text { healing of chronic ulcers: an experimental and } \\
\text { clinical. }\end{array}$ & 26 & Chronic ulcers & $\begin{array}{l}\text { surgical debridement } \\
\text { and intralesional } \\
\text { injection of PRP }\end{array}$ & $\begin{array}{l}10 \text { healed in } 7 \text { weeks, } 16 \text { underwent on } \\
\text { reconstructive procedure after woud bed } \\
\text { preparation with prp }\end{array}$ \\
\hline $\begin{array}{l}\text { Cervelli et al. Tissue regeneration in loss of } \\
\text { substance on the lower limbs through use of platelet- } \\
\text { rich plasma, stem cells from adipose tissue, and } \\
\text { hyaluronic acid. }\end{array}$ & 30 & $\begin{array}{l}\text { Various chronic } \\
\text { wounds }\end{array}$ & $\begin{array}{l}\text { Autologous prp }+ \text { fat } \\
\text { grafts }\end{array}$ & $\begin{array}{l}100 \% \text { improvement in } 3 \text { weeks, } 47 \% \\
\text { healing in } 6 \text { weeks, } 57 \% \text { healing in } 3 \\
\text { months }\end{array}$ \\
\hline $\begin{array}{l}\text { Sano et al. Treatment of chronic ulcer with elastic } \\
\text { plasma protein and platelet film for wound dressing. }\end{array}$ & 10 & Chronic wounds & $\begin{array}{l}\text { Plasma proteins }+ \\
\text { autologous prp: platelet- } \\
\text { protein film }\end{array}$ & $\begin{array}{l}\text { transcutaneous oxygen } \quad \text { tension } \\
\text { increased in } 4 \text { days, vascular density } \\
\text { increased in } 14 \text { days. }\end{array}$ \\
\hline $\begin{array}{l}\text { Park et al. Treatment of refractory venous stasis } \\
\text { ulcers with autologous platelet-rich plasma and light- } \\
\text { emitting diodes: a pilot study. }\end{array}$ & 16 & Venous ulcers & $\begin{array}{l}\text { Autologous prp + LED } \\
\text { therapy }\end{array}$ & $75 \%$ improved in 6 weeks \\
\hline $\begin{array}{l}\text { Salazar-Álvarez et al. Use of Platelet-Rich Plasma in } \\
\text { the Healing of Chronic Ulcers of the Lower Extremity. }\end{array}$ & 11 & $\begin{array}{l}\text { Non ischemic ulcers: } \\
\text { venous and } \\
\text { hypertensive ulcers }\end{array}$ & autologous & Improvement in 4 weeks \\
\hline
\end{tabular}

Table 1: Review of literature and medical cases of skin ulcers treated with PRP.

\section{Conclusion}

By applying PRP medications for a patient admitted at our hospital with non-Hodgkin linfoma, we succeed fully reduce the diameter of the pressure sore and to clear its bottom within 6 applications. This treatment ensured lower risk of infections and better quality of life for the patient which is very important for a patient in such a precarious condition.

PRP therapy improves and heals skin ulcers thanks to the combination of growth factors, anti-inflammatory mediators, antimicrobial effects and capacities to attract the undifferenciated cells 
Citation: Onesti MG, Fino P, Ferrazza G, Kaciulyte J, Scuderi N (2015) Decubitus Ulcer in a Patient with Non-Hodgkin Linfoma Treated with Topic Collagenase with Hyaluronic Acid and PRP: Case Report and Literature Review. J Blood Disord Transfus 6: 298. doi: $10.4172 / 2155-9864.1000298$

Page 5 of 5

and to improve the angiogenesis and re-epithelialization. Its use can lead to far better results in healing skin ulcers of patients, including the hematologic ones. Faster healing, reduced hospitalization, easy and patient friendly treatment mechanism without surgery or amputations are the unique advantages of PRP method. It ensures quality of life for the patients while reducing the hospital costs considerably.

The study suggests that in order to understand the PRP applications in healing sking sores and wounds it is essential to take up larger studies with a representative sample.

\section{Acknowledgments}

The authors hereby declare that they do not have any potential conflict of interests and did not receive funding for this work from any of the following organizations: National Institutes of Health (NIH); Welcome Trust; Howard Hughes Medical Institute (HHMI) and other(s). Each author participated sufficiently in the work to take public responsibility for the content.

Special thanks to Dr. Franco Bartolomei for his help in preparing this manuscript.

\section{References}

1. Agrawal K, Chauhan N (2012) Pressure ulcers: Back to the basics. Indian J Plast Surg 45: 244-254.

2. Cushing CA, Phillips LG (2013) Evidence-based medicine: pressure sores. Plast Reconstr Surg 132: 1720-1732.

3. Minniti CP, Delaney KM, Gorbach AM, Xu D, Lee CC, et al. (2014) Vasculopathy, inflammation, and blood flow in leg ulcers of patients with sickle cell anemia. Am J Hematol 89: 1-6.

4. Matta BN, Abbas O, Maakaron JE, Koussa S, Daderian RH, et al. (2014) Leg ulcers in patients with $\hat{\mathrm{I}}^{2}$-thalassaemia intermedia: a single centre's experience. J Eur Acad Dermatol Venereol 28: 1245-1250.

5. Campbell C, Parish LC (2010) The decubitus ulcer: facts and controversies. Clin Dermatol 28: 527-532.

6. Bernuzzi G, Tardito S, Bussolati O, Adorni D, Cantarelli S, et al. (2010) Platelet gel in the treatment of cutaneous ulcers: the experience of the Immunohaematology and Transfusion Centre of Parma. Blood Transfus 8: 237-247.

7. Orcajo B, Muruzabal F, Isasmendi MC, Gutierrez N, Sánchez M, et al. (2011) The use of plasma rich in growth factors (PRGF-Endoret) in the treatment of a severe mal perforant ulcer in the foot of a person with diabetes. Diabetes Res Clin Pract 93: e65-67.

8. Medina A, Scott PG, Ghahary A, Tredget EE (2005) Pathophysiology of chronic nonhealing wounds. J Burn Care Rehabil 26: 306-319.

9. Garber SL, Rintala DH (2003) Pressure ulcers in veterans with spinal cord injury: a retrospective study. J Rehabil Res Dev 40: 433-441.

10. Doucette MM, Fylling C, Knighton DR (1989) Amputation prevention in a high-risk population through comprehensive wound-healing protocol. Arch Phys Med Rehabil 70: 780-785.

11. Knighton DR, Fylling CP, Fiegel VD, Cerra F (1990) Amputation prevention in an independently reviewed at-risk diabetic population using a comprehensive wound care protocol. Am J Surg 160: 466-471.

12. Yamada N, Uchinuma E, Kuroyanagi Y (2012) Clinical trial of allogeneic cultured dermal substitutes for intractable skin ulcers. J Artif Organs 15: 193-199.
13. Scimeca CL, Bharara M, Fisher TK, Kimbriel H, Armstrong DG (2010) Novel use of platelet-rich plasma to augment curative diabetic foot surgery. J Diabetes Sci Technol 4: 1121-1126.

14. Slavkin HC, Bartold PM (2006) Challenges and potential in tissue engineering. Periodontol 2000 41: 9-15.

15. El-Sharkawy H, Kantarci A, Deady J, Hasturk H, Liu H, et al. (2007) Platelet-rich plasma: growth factors and pro- and anti-inflammatory properties. J Periodontol 78: 661-669.

16. Foster TE, Puskas BL, Mandelbaum BR, Gerhardt MB, Rodeo SA (2009) Platelet-rich plasma: from basic science to clinical applications. Am J Sports Med 37: 2259-2272.

17. Rozman P, Bolta Z (2007) Use of platelet growth factors in treating wounds and soft-tissue injuries. Acta Dermatovenerol Alp Pannonica Adriat 16: 156-165.

18. Everts PA, Knape JT, Weibrich G, Schönberger JP, Hoffmann J, et al. (2006) Platelet-rich plasma and platelet gel: a review. J Extra Corpor Technol 38: 174-187.

19. Sánchez M, Anitua E, Orive G, Mujika I, Andia I (2009) Platelet-rich therapies in the treatment of orthopaedic sport injuries. Sports Med 39: 345-354.

20. Creaney L, Hamilton B (2008) Growth factor delivery methods in the management of sports injuries: the state of play. Br J Sports Med 42: 314-320.

21. Alsousou J, Thompson M, Hulley P, Noble A, Willett K (2009) The biology of platelet-rich plasma and its application in trauma and orthopaedic surgery: a review of the literature. J Bone Joint Surg Br 91: 987-996.

22. Tang YQ, Yeaman MR, Selsted ME (2002) Antimicrobial peptides from human platelets. Infect Immun 70: 6524-6533.

23. Mishra A, Woodall J Jr, Vieira A (2009) Treatment of tendon and muscle using platelet-rich plasma. Clin Sports Med 28: 113-125.

24. Kim DH, Je YJ, Kim CD, Lee YH, Seo YJ, et al. (2011) Can Platelet-rich Plasma Be Used for Skin Rejuvenation? Evaluation of Effects of Plateletrich Plasma on Human Dermal Fibroblast. Ann Dermatol 23: 424-431.

25. Lacci KM, Dardik A (2010) Platelet-rich plasma: support for its use in wound healing. Yale J Biol Med 83: 1-9.

26. Margolis DJ, Kantor J, Santanna J, Strom BL, Berlin JA (2001) Effectiveness of platelet releasate for the treatment of diabetic neuropathic foot ulcers. Diabetes Care 24: 483-488.

27. Foster TE, Puskas BL, Mandelbaum BR, Gerhardt MB, Rodeo SA (2009) Platelet-rich plasma: from basic science to clinical applications. Am J Sports Med 37: 2259-2272.

28. Anitua E, Aguirre JJ, Algorta J, Ayerdi E, Cabezas AI, et al. (2008) Effectiveness of autologous preparation rich in growth factors for the treatment of chronic cutaneous ulcers. J Biomed Mater Res B Appl Biomater 84: 415-421.

29. Sell SA, Ericksen JJ, Reis TW, Droste LR, Bhuiyan MB, et al. (2011) A case report on the use of sustained release platelet-rich plasma for the treatment of chronic pressure ulcers. J Spinal Cord Med 34: 122-127.

30. Mehrannia M, Vaezi M, Yousefshahi F, Rouhipour N4 (2014) Platelet rich plasma for treatment of nonhealing diabetic foot ulcers: a case report. Can J Diabetes 38: 5-8.

31. Kim DH, Kim JY, Seo SH, Ahn HH, Kye YC, et al. (2012) Recalcitrant cutaneous ulcer of comorbid patient treated with platelet rich plasma: a case report. J Korean Med Sci 27: 1604-1606. 